\title{
The $A C E$ I allele is associated with increased risk for ruptured intracranial aneurysms
}

\author{
Mohammad Keramatipour, Robert S McConnell, Peter Kirkpatrick, Susan Tebbs, \\ Robert A Furlong, David C Rubinsztein
}

\begin{abstract}
Genetic and environmental factors play roles in the aetiology of ruptured intracranial aneurysms. Hypertension has been reported as a risk factor for intracranial aneurysm haemorrhage. We have tested if genotypes at the angiotensin converting enzyme $(A C E)$ gene locus are associated with ruptured intracranial aneurysms. The insertion/deletion polymorphism in the $A C E$ gene was genotyped in 258 subjects presenting in East Anglia with ruptured intracranial aneurysms (confirmed at surgery or angiographically) and 299 controls from the same region. $A C E$ allele frequencies were significantly different in the cases and the controls (alleles $\chi_{1}^{2}=4.67, \mathbf{p}=0.03$ ). The $I$ allele was associated with aneurysm risk (odds ratio for I allele $v \mathrm{D}$ allele $=1.3(95 \% \mathrm{CI}=1.02-1-$ 65 ); odds ratio for II $v$ DD genotype $=1.67$ $(95 \% \mathrm{CI}=1.04-2.66))$. The $\mathrm{I}$ allele at the ACE locus is over-represented in subjects with ruptured intracranial aneurysms. These data are supported by nonsignificant trends in the same direction in two previous smaller studies. Thus, this allele may be associated with risk for ruptured intracranial aneurysms.

(F Med Genet 2000;37:498-500)
\end{abstract}

Medical Genetics Cambridge University, Wellcome Trust Centre for the Study of Molecular

Mechanisms in Disease, Cambridge Institute for Medical

Research,

Addenbrooke's

Hospital, Hills Road,

Cambridge CB2 2XY,

UK

M Keramatipour

R A Furlong

D C Rubinsztein

Academic Department of Neurosurgery,

Addenbrooke's

Hospital, Hills Road,

Cambridge CB2 2QQ,

UK

R McConnnell

$S$ Tebbs

P Kirkpatrick

Correspondence to:

Dr Rubinsztein,

dcr1000@cus.cam.ac.uk

Revised version received 10 February 2000

Accepted for publication

16 February 2000 a cerebral aneurysm than the general population. ${ }^{5-7}$ Hypertension has been implicated as a risk factor for cerebral aneurysm by two large population based studies ${ }^{89}$ and in a family study. ${ }^{10}$ Blood pressure is partly regulated by angiotensin II, which is a potent arterial vasoconstrictor. Angiotensin II also increases aldosterone synthesis from the adrenal cortex and stimulates catecholamine synthesis and release from peripheral noradrenergic neurones. Angiotensin II is formed after cleavage of two carboxy-terminal amino acids from angiotensin I by angiotensin converting enzyme (ACE). ${ }^{11}$

The D allele of the insertion/deletion (I/D) polymorphism in intron 16 of the $A C E$ gene has been associated with higher circulating ACE levels in humans. ${ }^{12}$ Although the D allele has been associated with a number of cardiovascular diseases, like myocardial infarction ${ }^{13}$ and left ventricular hypertrophy, ${ }^{14}$ these findings have not been consistently replicated. ${ }^{15}$ Furthermore, this locus is not clearly associated with essential hypertension in humans. ${ }^{16}$ Recently, the I allele has been associated with risk for Alzheimer's disease, ${ }^{17}$ consistent with previous studies showing a depletion of the I allele in very elderly populations. ${ }^{18} 19$

Two previous studies have considered this $A C E$ polymorphism in the context of cerebrovascular haemorrhage. Catto et al ${ }^{20}$ studied 48 cases with intracerebral haemorrhage and 215 controls and Takenaka et $a l^{1}$ studied 83 cases with intracranial saccular aneurysms and 104 controls. Both studies showed a non-significant tendency for the I allele to be over-represented in cases. While Takenaka et $a l^{1}$ claimed that the DD genotype was significantly rarer in cases than controls $(p=0.044)$, this $p$ value did not take into account the multiple testing that should be considered when arbitrarily selecting the frequency of one out of three possible genotypes; one could have examined either the DD, DI, or II frequencies individually in cases and controls and this would constitute three tests. The overall genotype and allele frequencies in this study did not differ significantly in cases and controls (table 1).

The failure to detect effects in these studies may have been the result of type II errors, since the detection of small effects such as those expected in complex genetic diseases requires large samples. ${ }^{22}$ Accordingly, we have tested this polymorphism in our cohort of 258 cases with ruptured intracranial aneurysms and 299 regionally matched controls. 
Table 1 Allele and genotype frequencies at the ACE locus in cases with aneurysmal intracranial haemorrhage and controls. Data are shown from Cambridge and fapan. ${ }^{21}$ In the fapanese study the excess of the I allele did not reach statistical significance $\left(\chi^{2}=1.96, p=0.16\right)$ and the overall genotype distributions did not show significant differences between the cases and controls $\left(\chi_{2}^{2}=4.06, p=0.13\right)$

\begin{tabular}{lcc}
\hline Cambridge data & Controls (\%) & Cases (\%) \\
\hline Allele D & $310(51.8)$ & $234(45.3)$ \\
Allele I & $288(48.2)$ & $282(54.7)$ \\
Total & $598(100)$ & $516(100)$ \\
Genotype DD & $82(27.4)$ & $54(20.9)$ \\
Genotype DI & $146(48.8)$ & $126(48.8)$ \\
Genotype II & $71(23.7)$ & $78(30.2)$ \\
Total & $299(100)$ & $258(100)$ \\
fapanese data ${ }^{21}$ & & \\
Allele D & $77(37.0)$ & $50(30.1)$ \\
Allele I & $131(63.0)$ & $116(69.9)$ \\
Total & $208(100)$ & $166(100)$ \\
Genotype DD & $16(15.4)$ & $5(6.0)$ \\
Genotype DI & $45(43.3)$ & $40(48.2)$ \\
Genotype II & $43(41.3)$ & $38(45.8)$ \\
Total & $104(100)$ & $83(100)$ \\
\hline
\end{tabular}

\section{Methods}

PATIENT ASCERTAINMENT

This study was performed with the approval of the local ethics committee and informed consent was obtained from participating patients. The cases were 258 subjects ( 80 males, 178 females; mean age 52.8 years (SD 12.9 years)) who presented to Addenbrooke's Hospital with symptoms of intracranial haemorrhage and who had intracranial aneurysms confirmed angiographically or at surgery or both. The control samples comprised 297 subjects (126 males, 171 females; mean age 44.5 years (SD 13 years)) from an East Anglian population. These samples were anonymised and were obtained from the DNA Bank of the Molecular Genetics Laboratory, Addenbrooke's Hospital. Referral patterns to this laboratory suggest that at least $97 \%$ of controls were white, about $80 \%$ had parents who were East Anglian, and virtually all of the remainder were from the UK. The surnames of the controls and the cases were screened to exclude those obviously of non-white origin. It is important to note that this region of the UK includes a large rural catchment area and is not characterised by the ethnic variation seen in many large cities.

$A C E$ genotypes were determined using the "triple primer" method described by Evans et al. ${ }^{23}$ Meta-analysis and calculation of odds ratios with $95 \%$ confidence intervals was determined using unconditional logistic regression, with the general loglinear analysis option of SPSS version 6.1. This form of analysis can accommodate differences in control allele frequencies in different populations.

Table 2 Odds ratios from the Cambridge study and from a meta-analysis of the Cambridge and Fapanese ${ }^{21}$ dato

\begin{tabular}{lllll}
\hline & $\begin{array}{l}\text { Odds ratio } \\
\text { Cambridge data }\end{array}$ & $95 \%$ CI & $\begin{array}{l}\text { Odds ratio } \\
\text { Cambridge }+ \\
\text { fapanese data }\end{array}$ & $95 \%$ CI \\
\hline Allele I v D & 1.30 & $1.02-1.65$ & 1.31 & $1.06-1.62$ \\
Genotype II $v$ DD & $\chi_{1}^{2}=4.67, \mathrm{p}=0.03$ & 1.67 & $\chi_{1}^{2}=6.6, \mathrm{p}<0.02$ & $0.84-1.88$ \\
Genotype DI $v$ DD & 1.31 & $0.86-1.99$ & 1.26 & 1.05 \\
& $\chi_{2}^{2}=4.6, \mathrm{p}=0.1$ & & $\chi_{2}^{2}=1.6, \mathrm{p}>0.3$ & $0.73-1.51$ \\
\hline
\end{tabular}

\section{Results}

The DD, DI, and II genotype frequencies in the Cambridge controls were $27.4 \%, 48.8 \%$, and $23.7 \%$, respectively, and were very similar to those expected under Hardy-Weinberg expectations $(26.7 \%, 49.8 \%$, and $23.1 \%$, respectively; $\left.\chi_{2}^{2}=0.082, \mathrm{p}=0.96\right)$. Allele frequencies differed significantly in the Cambridge patients with intracranial aneurysm versus controls (table 1$)\left(\chi_{1}^{2}=4.67, \mathrm{p}=0.03\right)$. The odds ratio for aneurysmal intracranial haemorrhage for the I allele versus the D allele was 1.30 (95\% CI=1.02-1.65). The overall genotypes of the aneurysm cases were not significantly different from the control group $\left(\chi_{2}^{2}=4.6, p=0.1\right)$. However, there was a tendency for the II genotype to be overrepresented and the DD genotype to be underrepresented in cases versus controls, OR for II $v \mathrm{DD}=1.67(95 \% \mathrm{CI}=1.04-2.66)($ table 2$)$.

The only previous analysis of this gene in patients with aneurysmal intracranial haemorrhage was the study of Takenaka et $a l^{21}$ (table 1). A meta-analysis of their data in a Japanese sample together with our Cambridge sample showed a significant effect for alleles $\left(\chi_{1}^{2}=6.6\right.$, $\mathrm{p}<0.02)$. The odds ratio for aneurysmal intracranial haemorrhage in this meta-analysis for the I allele versus the D allele was 1.31 (95\% $\mathrm{CI}=1.06-1-62$ ) (table 2). The meta-analysis of the genotype data did not yield a significant difference, but again there was a tendency for the II genotype to be over-represented in aneurysm cases versus controls. The data from Catto et $a l^{20}$ were not included in the meta-analysis, as they analysed cases with intracranial haemorrhage, without specifying the diagnosis (aneurysms account for $<1 / 3$ of cases with intracranial haemorrhage).

\section{Discussion}

Multifactorial diseases are likely to involve a number of different contributing genes. Thus, the effect of any particular gene will be expected to be modest, contributing odds ratios of 2 or less. ${ }^{22}$ Our data suggest that the I allele at the $A C E$ locus may be associated with the presentation of ruptured intracranial aneurysms. The findings in the Cambridge population show the same trends as observed in Japanese $^{21}$ and in the study of Catto et al, ${ }^{20}$ who examined cases with intracranial haemorrhage, without specifying the diagnosis. Our failure to observe a significant difference in overall genotype frequency in the face of a significant difference in allele frequency is probably because of the modest effect and the fact that analyses of alleles doubles the numbers of observations and compares only two states, as compared to three states for genotypes. Thus, analysis of allele frequencies can be associated with greater power under a multiplicative model.

It is interesting that the I allele is associated with increased risk for intracranial aneurysm rupture. Some studies have observed an association between the $\mathrm{D}$ allele and increased cardiovascular disease risk, but these findings are controversial. Conversely, the D allele has been associated with increased longevity in two 
studies $^{1819}$ and the I allele has recently been reported to be associated with risk for Alzheimer's disease. ${ }^{17}$

While the $\mathrm{D}$ allele is associated with higher circulating ACE activity, this does not appear to be a causal consequence of the deletion/ insertion mutation. ${ }^{24}$ Thus, the causal variant is likely to be in linkage disequilibrium with this polymorphism. It is interesting to note that the I allele frequency is higher in Japanese compared to the Cambridge population and this is paralleled by the higher incidence of intracranial aneurysm rupture in the Japanese population. ${ }^{25}$ This may be because of a higher frequency of a functional variant in linkage disequilibrium with this allele, or alternatively this may be coincidental. It is difficult to predict what the functional basis of the observed association of the I allele and ruptured intracranial aneurysms is. One possibility is a modulation of feedback loops involving blood pressure regulation. However, ACE has other roles which may be relevant to aneurysm formation. For instance, angiotensin II has an inotropic and chronotropic effect in the heart ${ }^{26}$ and regulates vascular growth. ${ }^{27}$ Furthermore, as ACE degrades bradykinin and related kinins ${ }^{28}$ it may modulate the risk of intracranial aneurysmal haemorrhage via these peptides, since kinins relax vascular smooth muscle. ${ }^{11} \mathrm{At}$ present, it is difficult to predict if the putative associations of the $A C E$ I allele with intracranial aneurysm and Alzheimer's disease risk are mediated via the same physiological pathways.

In summary, while ruptures of intracranial aneurysms are comparatively common and are associated with a modest familial risk, there are very few studies aiming to identify specific genetic risk factors. Our data implicate the $A C E$ gene in the pathogenesis of this condition. Further large studies will be required to confirm this association.

This work was supported by a grant from the Anglia and Oxford Regional Health Authority, the Iranian Ministry of Health and Medical Education (MK), Friends of Peterhouse, and The Isaac Newton Trust. RAF is a Peterhouse Senior Research Associate. DCR is a Glaxo Wellcome Research Fellow.

1 Schievink WI, Wijdicks EF, Parisi JE, Piepgras DG, Whisnant JP. Sudden death from aneurysmal subarachnoid hemorrhage. Neurology 1995;45:871-4.

2 Kassell NF, Torner JC, Haley EC Jr, Jane JA, Adams HP, Kongable GL. The International Cooperative Study on the Timing of Aneurysm Surgery. Part 1. Overall managemen results. F Neurosurg 1990;73:18-36.

3 Butler WE, Barker FG II, Crowell RM. Patients with polycystic kidney disease would benefit from routine magnetic resonance angiographic screening for intracerebral aneurysms: a decision analysis. Neurosurgery 1996;38:50615.

4 Schievink WI, Limburg M, Oorthuys JW, Fleury P, Pope FM. Cerebrovascular disease in Ehlers-Danlos syndrome type IV. Stroke 1990;21:626-32.

5 Leblanc R, Melanson D, Tampieri D, Guttmann RD. Familial cerebral aneurysms: a study of 13 families. Neurosurgery 1995;37:633-8.

6 Bromberg JE, Rinkel GJ, Algra A, Greebe P, van Duyn CM, Hasan D, Limburg M, ter Berg HW, Wijdicks EF, van Gijn
J. Subarachnoid haemorrhage in first and second degree relatives of patients with subarachnoid haemorrhage. BMf relatives of patie

7 De Braekeleer M, Perusse L, Cantin L, Bouchard JM, Mathieu J. A study of inbreeding and kinship in intracranial aneurysms in the Saguenay Lac-Saint-Jean region (Quebec, Canada). Ann Hum Genet 1996;60:99-104.

8 Taylor CL, Yuan Z, Selman WR, Ratcheson RA, Rimm AA. Cerebral arterial aneurysm formation and rupture in 20,767 elderly patients: hypertension and other risk factors. $\mathcal{F}$ Neurosurg 1995;83:812-19.

9 Knekt P, Reunanen A, Aho K, Heliovaara M, Rissanen A, Aromaa A, Impivaara O. Risk factors for subarachnoid hemorrhage in a longitudinal population study. $\mathcal{f}$ Clin Epidemiol 1991;44:933-9.

10 Alberts MJ, Quinones A, Graffagnino C, Friedman A, Roses AD. Risk of intracranial aneurysms in families with subarachnoid hemorrhage. Can f Neurol Sci 1995;22:1215.

11 Ganong WF. Review of medical physiology. 10th ed. Los Alton: Lange Medical Publications, 1981:364-5.

12 Rigat B, Hubert C, Alhenc-Gelas F, Cambien F, Corvol P, Soubrier F. An insertion/deletion polymorphism in the angiotensin I converting enzyme gene accounting for half the variance of serum enzyme levels. F Clin Invest 1990;86: 1343-6.

13 Cambien F, Costerousse O, Tiret L, Poirier O, Lecerf L, Gonzales MF, Evans A, Arveiler D, Cambou JP, Luc G, Rakotovao R, Ducimetiere P Soubrier F, Alhenc-Gelas F. Plasma level and gene polymorphism of angiotensinconverting enzyme in relation to myocardial infarction. Circulation 1994;90:669-76.

14 Iwai N, Ohmichi N, Nakamura Y, Kinoshita M. DD genotype of the angiotensin-converting enzyme is a risk factor for left ventricular hypertrophy. Circulation 1994;90:2622-
for 8.

15 Kupari M, Perola M, Koskinen P, Virolainen J, Karhunen PJ. Left ventricular size, mass and function in relation to ngiotensin-converting enzyme gene polymorphism in humans. Am F Physiol 1994;267:H1107-11.

16 O'Byrne S, Caulfield M. Genetics of hypertension. Therapeutic implications. Drugs 1998;56:203-14.

17 Kehoe PG, Russ C, McIlroy S, Williams H, Holmans P, Holmes C, Liolitsa D, Vahidassr D, Powell J, McGleenon B, Liddell M, Plomin R, Dynan K, Williams N, Neal J, Cairns NJ, Wilcock G, Passmore P, Lovestone S, Williams $\mathrm{J}$, Owen MJ. Variation in DCP1, encoding ACE, is associated with susceptibility to Alzheimer disease. Nat Genet 1999;21:71-2.

18 Schachter F, Faure-Delanef L, Guenot F, Rouger H, Froguel P, Lesueur-Ginot L, Cohen D. Genetic association with human longevity with the APOE and ACE loci. Nat Genet 1994;6:29-32

19 Galinsky D, Tysoe C, Brayne CE, Easton DF, Huppert FA, Dening TR, Paykel ES, Rubinsztein DC. Analysis of the apo E/apo C-I, angiotensin converting enzyme and methylene tetrahydrofolate reductase genes as candidates affecting human longevity. Atherosclerosis 1997;129:177-83.

20 Catto A, Carter AM, Barrett JH, Stickland M, Bamford J, Davies JA, Grant PJ. Angiotensin-converting enzyme insertion/deletion polymorphism and cerebrovascular disinsertion/deletion polymorph.

21 Takenaka K, Yamakawa H, Sakai H, Yoshimura S, Murase S, Okumura A, Nakatani K, Kimura T, Nishimura Y, Yoshimi N, Sakai N. Angiotensin I-converting enzyme gene polymorphism in intracranial saccular aneurysm individuals. Neurol Res 1998;20:607-11.

22 Todd JA. Interpretation of results from genetic studies of multifactorial diseases. Lancet 1999;354:SI15-16.

23 Evans AE, Poirier O, Kee F, Lecerf L, McCrum E, Falconer T, Crane J, O'Rourke DF, Cambien F. Polymorphisms of the angiotensin-converting-enzyme gene in subjects who die from coronary heart disease. $O$ f Med 1994;87:211-14.

24 Rosatto N, Pontremoli R, De Ferrari G, Ravazzolo R. Intron 16 insertion of the angiotensin converting enzyme gene and 16 insertion of the angiotensin converting enzyme gene and transcrip

25 Youmans JR, ed. Neurological surgery. Philadelphia: Saunders, 1982:1627.

26 Falkenhahn M, Gohlke P, Paul M, Stoll M, Unger T. The renin-angiotensin system in the heart and vascular wall: new therapeutic aspects. F Cardiovasc Pharmacol 1994; 24(suppl 2):S6-13.

27 Dzau VJ. Cell biology and genetics of angiotensin in cardiovascular disease. F Hypertens Suppl 1994;12:S3-10.

28 Linz W, Wiemer G, Gohlke P, Unger T, Scholkens BA. Contribution of kinins to the cardiovascular actions of angiotensin-converting enzyme inhibitors. Pharmacol Rev 1995;47:25-49. 